\title{
21. The Japanese Equivalents of the Lepidopteris and Thaumatopteris Zones of East Greenland.
}

\author{
By Saburô ÔISHI. \\ Department of Geology and Mineralogy, Hokkaido Imperial University, Sapporo. \\ (Comm. by H. YABE, M.I.A., Feb. 12, 1938.)
}

The Nariwa Series of the Nariwa district is a thick complex of terrestrial origin with abundant fossil plants in certain horizons indicating Rhaetic to Liassic periods, and brought into juxtaposition with a marine formation rich in a Noric species of Pseudomonotis by dislocations.1) The terrestrial formation being also traversed by many faults, it is a matter of difficulty to decide the relative stratigraphical sequence among plant beds exposed at numerous localities in Nariwa except for a few cases in which they are stratigraphically continuous. The present writer ${ }^{2}$ once stated that the greater parts of the fossiliferous beds represent the Rhaetic, while it is probable from the occurrence of some Liassic elements in the fossil plants from certain localities that the upper part of this thick complex may be slightly younger, thus suggesting the probable existence of at least two main floral zones differing in age.

For the purpose to judge the tenability of this view, the floral lists of the Lepidopteris (Rhaetic) and Thaumatopteris (Basal Liassic) Zones of Scoresby Sound in East Greenland studied by T. M. Harris ${ }^{3 \prime}$ have been compared with those of each locality in Nariwa, since the two districts are in the same geobotanical province and there are a good deal of important common genera and species in their floras. The result is outlined below.

The main fossil localities in Nariwa are about 30 in number, of which more than half contain certain genera and species characteristic to either the Lepidopteris- or the Thaumatopteris Zone.

The plant beds of the following localities ${ }^{4}$ contain one or more species which occur from the Lepidopteris Zone only and never mixed with any species restricted to the Thaumatopteris Zone; the localities, the respective species and the association are as follows:

Loc. 1. Neocalamites hoerensis, Pterophyllum Schenki.

1) S. Oishi: The Rhaetic Plants from the Nariwa District, Prov. Bitchû (Okayama Pref.) Japan. Jour. Fac. Sci. Hokkaidô Imp. Univ., Ser. IV, Vol. 1, Nos. 3-4, 1932.

2) S. Ôishi : Yabeiella sp. from the Japanese Triassic. Jap. Jour. Geol. Geogr., Vol. VIII, No. 4, 1931.

3) T. M. Harris: The Fossil Flora of Scoresby Sound, East Greenland. Pt. I, Med. om Gronland, Bd. LXXXV, No. 2 (1931); Pt. 2, Ibid., No. 3 (1932); Pt. 3, Ibid., No. 5 (1932); Pt. 4, Ibid., Bd. CXII, No. 1 (1935); Pt. 5, Ibid., No. 2 (1937).

4) As to the geographical position of each locality, see Pl. I in S. Oishi and K. Huzioka: Fossil Plants From Nariwa. A Supplement. Jour. Fac. Sci., Hokkaidô Imp. Univ., Ser. IV, Vol. IV, Nos. 1-2, 1938 (in preparation). 
Association: Annulariopsis inopinata?, Cladophlebis nebbensis, Clathropteris meniscoides, C. meniscoides var. elegans, Thaumatopteris nipponica, T. pusilla, Hausmannia nariwaensis, $H$. crenata, ${ }^{1)} H$. dentata, Taeniopteris cfr. Carruthersi, Nilssonia simplex, Baiera Muensteriana, ${ }^{2)}$ Czekanowskia rigida, Pityophyllum longifolium, Elatocladus plana, E. tenerrima, Podozamites Schenki, P. lanceolatus, P. concinnus, ${ }^{*}$ Nageiopsis rhaetica, Drepanozamites? sp. indet. ${ }^{3)}$

Loc. 45. Neocalamites hoerensis.

Association: Clathropteris obovata, Podozamites lanceolatus.

Loc. 48. Neocalamites hoerensis.

Association: Todites Roesserti Zeill. (non Presl) $=$ Todites goeppertianus, Cladophlebis haiburnensis, C. Raciborskii forma integra, Thaumatopteris elongata, Nilssonia Muensteri, Czekanowskia rigida.

Loc. 55. Pterophyllum Schenki.

Association: Cladophlebis nebbensis, Podozamites lanceolatus.

Loc. 63. Pterophyllum Schenki.

Association: Annulariopsis inopinata?, Cladophlebis denticulata, Clathropteris meniscoides, C. meniscoides var. elegans, Thaumatopteris Kochibei, T. pusilla, Dictyophyllum Muensteri, Hausmannia nariwaensis, Pterophyllum serratum,* Taeniopteris nabaensis, Stenorachis elegans, Podozamites Schenki, P. lanceolatus, $P$. concinnus.*

Localities $16,21,50$ and 62 do not yield species characteristic to either the Lepidopteris- or the Thaumatopteris Zone, but contain certain species closely allied to the elements of Lepidopteris flora, and none allied to those of Thaumatopteris flora, viz.:

Loc. 16. Baiera Muensteriana, closely allied to Ginkgoites minuta.

Association: Annulariopsis inopinata?, Cladophlebis denticulata, Podozamites lanceolatus.

Loc. 21. Ctenis japonica, closely allied to C. nilssoni.

Association: Taeniopteris nabaensis, Cfr. T. minensis, $T$. cfr. Carruthersi, Nilssonia acuminata, Gingkoites sibirica, Baiera filiformis, Czekanowskia rigida, Pityophyllum longifolium, Podozamites lanceolatus.

Loc. 50. Baiera Muensteriana, closely allied to Ginkgoites minuta, and Taeniopteris lanceolatus, closely allied to T. tenuinervis.

Association: Neocalamites Carrerei, Cladophlebis haiburnensis, $C$. denticulata, Clathropteris meniscoides var. elegans, Pterophyllum aequale, P. jaegeri, Ptilozamites tenuis, Ctenis Yabei, C. Takamiana*, Baiera Muensteriana, B. elegans, Stenorachis Konianus,* Pityophyllum longifolium, Podozamites lanceolatus.

Loc. 62. Ptilozamites Nillsoni?, closely allied to P. nilssoni.

Association: Cladophlebis nebbensis, Clathropteris obovata, Cfr. Pterophyllum distans, Campylophyllum hoermanni. ${ }^{4}$

1) Harris regards $H$. crenata as an element of Lepidopteris flora.

2) Closely allied to Ginkgoites minuta, an element of Lepidopteris flora.

3) Allied to D. nilssoni (Nath.) Harris.

$*$ The species with an asterisk denote new species, to be described in a forthcoming paper by Ôishi and Huzioka: Op. cit.

4) The identification of the Japanese specimen to C. hoermanni is now slightly doubtful. Harris states that the species is of the Thaumatopteris flora. 
The following localities yield one or more species occurring in the Thaumatopteris Zone only and none restricted to the Lepidopteris Zone: the localities, the respective species and the association are as follows:

Loc. 44. Marattiopsis Muensteri, Swedenborgia major.

Association: Todites Williamsoni, Cladophlebis haiburnensis, $C$. gigantea, C. bitchuensis, C. nebbensis, C. Raciborskii, C. Raciborskii forma integra, C. subplectrophora, ${ }^{*}$ C. tenue, C. pseudodelicatula, Clathropteris obovata, Sphenopteris gracilis, Pterophyllum Jaegeri, Taeniopteris nabaensis, Nilssonia orientalis, Ctenis sp., Ginkgoites sibirica, Baiera paucipartita, Czekanowskia rigida, Phoenicopsis sp., Podozamites lanceolatus, Swedenborgia cryptomerioides.

Loc. 49. Marattiopsis Muensteri, Todites princeps, Dictyophyllum Muensteri, D. Nilssoni.

Association: Equisetites multidentatus, Neocalamites Carrerei, Cladophlebis Raciborskii forma integra, C. denticulata, Clathropteris obovata, Thaumatopteris elongata, Cfr. T. Brauniana, Nilssonia Muensteri, Ginkgoites sibirica, Phoenicopsis sp., Pityophyllum longifolium, Podozamites lanceolatus.

Loc. 64. Dictyophyllum Nilssoni.

Association: Taeniopteris cfr. Leclerei.

Loc. 66. Baiera taeniata, closely allied to Ginkgoites hermelini.

Association: Todites Williamsoni, Nilssonia acuminata, Ginkgoites digitata var. Huttoni, Baiera taeniata.

Association: Elatocladus sp.

Loc. 87. Dictyophyllum Nilssoni.

Association: Cladophlebis haiburnensis.

Locality 91 yields Cfr. Storgaardia spectabilis which probably is specifically identical with $S$. spectabilis, an element of Thaumatopteris flora; the association is Cladophlebidium? okayamaensis*

The plant beds from the following localities contain species occurring in the transition beds between Lepidopteris- and Thaumatopteris Zone only and are free from those restricted to either one of the two zones; the localities, the respective species and association are as follows:

Loc. 65. Swedenborgia cryptomerioides.

Association: Taenioperis? sp. nov., Podozamites lanceolatus.

Loc. 68. Cfr. Thaumatopteris Brauniana.

No association.

Loc. 69. Swedenborgia cryptomerioides.

Association: Phyllotheca sp. = ? Swedenborgia cryptomerioides, Cladophlebis nebbensis, C. denticulata, Clathropteris obovata, Baiera sp., Czelcanowskia rigida, Pityophyllum longifolium, Podozamites lanceolatus.

The above comparison shows that the fossil species restricted to either the Lepidopteris or the Thaumatopteris Zone at Scoresby Sound are always found in separate localities of Nariwa, and never mixed with the species restricted to the other Zone. This analogy held be- 
tween the fossil floras of Scoresby Sound and those of Nariwa is marked; may it be accidental?, or does it suggest the probable far eastern extension of these floral zones to the Nariwa district?

The conclusion to which the present writer has reached from solely the palaeobotanical point of view is that, among plant beds of many fossil localities in the Nariwa district, those of Locs. 1, 45, 48, 55,63 certainly and of Loes. 16, 21, 50, 62 probably correspond to the Lepidopteris Zone, while those of Locs. 44, 49, 64, 66, 86, 87 certainly and of Loc. 91 probably correspond to the Thaumatopteris Zone.

In the end, the present writer tenders his grateful acknowledgement to Prof. $H$. Yabe, from whom he has received many kind criticisms and advices in preparing this note. 